MARIJANA JOVELIĆ, viši kustos, istoričar

Vojni muzej

UDK 32.019.51(497.11)"1941"

Beograd, Kalemegdan bb

\title{
PARTIZANSKA PROPAGANDA U SRBIJI 1941. U ARHIVSKOJ GRAĐI VOJNOG MUZEJA
}

\begin{abstract}
APSTRAKT: Cilj rada jeste da pokaže glavne karakteristike partizanske propagande u Srbiji 1941. godine, istražene na osnovu arhivske građe Vojnog muzeja. Najviše je dokumenata koji potvrđuju glavnu intenciju partizanske propagande ka glorifikovanju SSSR-a. Drugu grupu čine dokumenta koja odslikavaju favorizovanje socijalne revolucije od strane partijskog i partizanskog rukovodstva, potencirane u odnosu na oslobodilačku komponentu partizanske borbe. Tek na trećem mestu, po brojnosti, jesu arhivalije koje govore o nacionalno-oslobodilačkom karakteru narodnooslobodilačke borbe.
\end{abstract}

Ključne reči: Partizanska propaganda, Ravnogorski pokret, socijalna revolucija, Sovjetski Savez, Srbija 1941.

Partizanska propaganda je imala tri karakteristična sloja, kako u svojim istraživanjima navodi dr Kosta Nikolić. ${ }^{1}$ Prvi, osnovni i najizrazitiji ogledao se $\mathrm{u}$ težnji partizanskog pokreta da kroz agitaciono-propagandnu delatnost pruži neiscrpnu podršku SSSR-u. Drugi pravac očituje se u insistiranju na socijalnoj, komunističkoj revoluciji i kao takav je zdušno propagiran i popularisan kroz partizansku štampu. Ipak, te 1941. godine, partijsko i partizansko rukovodstvo mudro i taktizerski istupa sa parolama klasne borbe, jer je moralo voditi računa da ne izazove ljutnju sovjetskog saveznika koji je stalno insistirao na strogo ograničenoj platformi oslobodilačkog i antifašističkog, ne revolucionarnog rata, da ne bi izazvao podozrenje saveznika do kojeg mu je bilo najviše stalo, a to je bila Velika Britanija u antihitlerovskoj koaliciji. Drugi razlog opreznosti u smislu odsustva suviše transparentnog razmahivanja revolucionarnim parolama te 1941. godine, bila je bojazan partijskog i partizanskog rukovodstva da će forsiranjem klasnog

${ }^{1}$ Kosta Nikolić, Ustanak u Srbiji 1941, istorijske posledice, „Museum“, Godišnjak Narodnog muzeja u Šapcu, 12, Šabac 2011, 178-179. 
karaktera narodnooslobodilačke borbe i njegove revolucionarne note nužno izazvati reakciju kvislinške propagande koja bi jedva dočekala da partizanski pokret optuži kao destruktivan, anacionalni i razarački, sa jedinim ciljem osvajanja vlasti. Treći sloj propagandne aktivnosti, zapravo tek poslednji, bio je favorizovanje oslobodilačke borbe partizanskog pokreta. Arhivska građa Vojnog muzeja u najvećoj meri sadrži dokumenta koja se odnose na popularizaciju SSSR-a i njegove antifašističke borbe, potom dokumenta KPJ koja imaju cilj svojevrsnu apologezu njenih programskih ciljeva i zadataka, a na trećem mestu po učestalosti prisustva, jesu arhivalije koje veličaju borbene akcije i dejstva partizanskih odreda. U zbirci Vojnog muzeja najviše je arhivalija koje veličaju i slave SSSR, i govore u prilog tvrdnji dr Nikolića.

Po brojnosti, na drugom mestu su odista arhivalije koje popularišu ciljeve i zadatke politike KPJ u smislu glorifikacije socijalne revolucije, a tek na trećem mestu jesu arhivalije koje veličaju i iscrpno govore o oslobodilačkim, borbenim akcijama partizanskih odreda. Razmatrana 1941. godina, donela je mnoštvo različitih sadržajnih elemenata partizanske štampe. O njima smo već govorili. Ipak, arhivska građa Vojnog muzeja koja pokriva pitanje partizanske propagande u Srbiji 1941. godine, može se podeliti na tri osnovne grupe.

U prvu grupu spadaju arhivalije čija je bazična sadržajna karakteristika popularizacija i davanje podrške antifašističkoj borbi SSSR-a. Druga grupa arhivalija su dokumenta koja pored sadržajnog elementa glorifikacije SSSR-a i njegove borbe, donose i neke druge sadržajne elemente, i treća grupa dokumenata, kojih je uzgred i najmanje, jesu arhivalije koje karakterišu sadržajni elementi koji nisu striktno vezani za pominjanje SSSR-a.

Istaknimo jedan Izveštaj partijskih i partizanskih rukovodstava iz 1941. Reč je o listu pod nazivom Naš izveštaj. Hitlerova vojska se u pomenutom dokumentu naziva razbojničkom, pominju se fašističke bande i horde, izrodi i zveri. S druge strane, Crvena armija se naziva nepobedivom i herojskom. ${ }^{2}$ U Izveštaju od 9. novembra 1941, podrobno je opisan Staljinov govor povodom proslave godišnjice Oktobarske revolucije na Crvenom trgu u Moskvi. U njemu se veličanstvenim tonovima, sa mnogo patosa, uzdiže značaj SSSR-a u svetskoj revoluciji i oslobađanju od fašizma. Staljin nakon samo četiri meseca borbe govori o propasti Hitlerovog munjevitog rata, istakavši egzaltiranim masama da je savez sovjetskih radnika i seljaka jači no ikada. $^{3}$ Staljinov govor novembra 1941, u stvari, jačao je iluzije u vođstvu NOP-a o brzom završetku rata i uticao je na strateška opredeljenja NOP-a. U Izveštaju od 6. oktobra 1941, iznesen je žučan napad na Hitlera koji je

\footnotetext{
${ }^{2}$ Vojni muzej, Arhivska građa, i. b. 18486, Izveštaj, list JNOF-a Dalmacije iz 1941.

${ }^{3}$ VM, AG, i. b. 18480, Izveštaj, 9. novembar 1941.
} 
nazvan lažljivcem i političkom varalicom i lupežom, jer „vara nemački narod" obmanjujući ga lažnim ciframa o nemačkim gubicima na Istočnom frontu. U tekstu se takođe govori da su 1. oktobra 1941, nemačke radio-stanice otvoreno objavile da je Hitlerov munjevit rat protiv Sovjetskog Saveza definitivno propao. ${ }^{4}$ Pomena vredan je Izveštaj br. 3a, za 1941. godinu, u stvari tekst na srpskohrvatskom jeziku, latinici, umnožen na geštetneru na belom papiru, na dve numerisane strane formata 34 x $21 \mathrm{~cm}$. Njime se iznosi Staljinov govor o „verolomstvu“ Hitlera i Ribentropa i naglašava kako ceo sovjetski narod stoji uz Crvenu armiju. Tekst ističe potrebu mobilisanja svih potencijala za odbranu zemlje. Govori da u sovjetskim redovima ne sme da bude sabotera, paničara i kukavica, već samo požrtvovanih i samopregornih ljudi. Ovaj izveštaj vatreno govori o nameri SSSR-a da svojim saveznicima sistematski i intenzivno razvije svest o tome da nije reč samo o borbi SSSR-a da likvidira opasnost po svoju zemlju, nego da je cilj pružanje „pomoći svim zarobljenim narodima“. Reč demokratija se takođe neprimereno koristi kao cilj borbe SSSR-a protiv „fašističkog porobljivača“. Takođe, u strastvenom govoru Komitetu za narodnu odbranu, Staljin ističe neumitnu potrebu da se na svaki način predupredi pogubna neprijateljska propaganda. ${ }^{5}$

U Izveštaju od 7. jula 1941, govori se o „sudbonosnom istorijskom poslanju“ SSSR-a da oslobodi svet od „varvarstva.“6 Izveštaj br. 10 iz 1941. godine, slikovito i jezikom mržnje ističe kako će sve „krvoločne fašističke divizije i ljudožder Hitler, biti pretvoreni u prah i pepeo". Nijedan fašistički „pljačkaš“, kako se kaže u tekstu, neće živ otići iz sovjetske zemlje. Tu će mu biti grob. U ovom tekstu partizanska propaganda pokušava da preuveliča herojstvo crvenoarmejaca i negira dobro poznati faktor ruske zime koji je, svakako, doprineo porazu Hitlera u munjevitom ratu. ${ }^{7}$ Interesantno je da se u gotovo svim Izveštajima iz 1941. godine koji sadrže isključivo sadržajnu karakteristiku veličanja uloge i rata SSSR-a, iznosi istovremeno njegov status svojevrsne „žrtve“. Drugim rečima, htelo se naglasiti u partizanskoj propagandi da je SSSR potpuno nevino stupio u rat za razliku od Hitlera koji je svesno i podmuklo prekršio pakt o nenapadanju Ribentrop-Molotov. Taj status „nevine žrtve“ kao da je imao ulogu da samo potencira želju partizanske propagande da naglasi „natčovečansko“ junaštvo crvenoarmejaca i istakne velike gubitke koji su naneti fašističkom neprijatelju, a kojima se sovjetska ratna mašinerija sigurno veoma ponosila.

Partizanska propaganda je neprestano pokušavala da stvori atmosferu sovjetske nevinosti time što je u svojim napisima potencirala oslobodi-

\footnotetext{
${ }^{4}$ VM, AG, i. b. 18457, Izveštaj, 6. oktobar 1941.

${ }^{5} \mathrm{VM}, \mathrm{AG}, \mathrm{i}$. b. 18421, Izveštaj, br. 3a za 1941.

${ }^{6} \mathrm{VM}, \mathrm{AG}, \mathrm{i}$. b. 18424, Izveštaj, 7. jul 1941.

${ }^{7}$ VM, AG, i. b. 18410, Izveštaj, br. 10 od 1941.
} 
lački i odbrambeni sovjetski rat protiv fašističkog neprijatelja, želeći da na neki način negira bilo kakve Staljinove pretenzije u jednom ratu koji je, sa stanovišta velikih sila, vođen radi preraspodele moći u svetu. O rečenom svedoči list Vesti od 3. oktobra 1941. Tu se eksplicitno kaže da „zemljište i tle nije i ne može biti cilj za sovjetsku zemlju. Čovek i jedino čovek za nju je cilj“. U tekstu se, uz dozu patosa, iznose Staljinove reči da „ono što je u njegovoj zemlji najdragocenije, jeste svaka kap krvi crvenog vojnika. Otud nije važno sačuvati u bici tle koje je samo sredstvo za proizvodnju, već sačuvati narod, sračunati takvu borbu u kojoj će sovjetski narod podneti najmanje moguće žrtve i pobediti napadača. Sasvim je svejedno na kom mestu, na kojoj teritoriji će sistematsko uništenje dostići stupanj potpunog razorenja neprijatelja i nije važno da li je neprijatelj dotada izvodio defanzive ili ofanzive, važno ga je uništiti i sačuvati svoj narod". ${ }^{8}$ Dalje, u istom dokumentu se iznosi: „Ali nova sovjetska strategija, za koju čovek nije sredstvo nego jedini mogući veliki cilj i koja je sva sistematski sračunata na uništenje zavojevačkog fašističkog napadača koji unižava čoveka tako kako nije nikada bio unižen, moćno rukovodi herojsku Crvenu armiju da u savezu sa Velikom Britanijom konačno uništi fašističkog dželata, najstrahovitiju kugu koja je ikada morila čovečanstvo. “9

Popularizacija SSSR-a u arhivskoj građi Vojnog muzeja i afirmativan stav prema borbi sovjetskog naroda dovođen $u$ vezu sa davnašnjim prijateljskim relacijama između dva slovenska naroda, imali su izgleda još jedan cilj. Reč je o veštom taktiziranju u sprovođenju propagande budući da je partijsko i partizansko rukovodstvo težilo da istovremeno obezbedi pozitivan stav zapadnih saveznika radi pribavljanja neophodne materijalne i vojne pomoći. To je bilo važno upravo te 1941. godine kada je Velika Britanija podržavala Ravnogorski pokret Draže Mihailovića. Draža Mihailović šalje Izveštaj o stanju u zemlji na dan 1. oktobra 1941. godine. ${ }^{10}$ Već sledećeg meseca, tačnije 15. novembra 1941, Draža je preko Radio Londona promovisan od predsednika vlade u emigraciji Dušana Simovića, za komandanta svih jugoslovenskih snaga $\mathrm{u}$ zemlji. ${ }^{11}$ Rad partijskog i partizanskog rukovodstva na pridobijanju britanskog saveznika neumitno bi zasmetao Kominterni i Sovjetskom Savezu. Zato je, pretpostavljamo, propagandno-agitaciona aktivnost minuciozno potencirala prvenstvo prijateljstva i dobrih odnosa sa SSSR-om kao najvažnijim saveznikom. Takođe, intenzivno naglašavanje bratskih i prijateljskih veza sa SSSR-om imalo je još jedan konkretan cilj. Trebalo je, naime, eliminisati izvesnu disharmoniju u odnosima

\footnotetext{
${ }^{8}$ VM, AG, i. b. 18391, Vesti, 3. oktobar 1941.

${ }^{9}$ Isto.

${ }^{10}$ V. Đuretić, Saveznici i jugoslovenska ratna drama, I, knj. 23, Beograd 1985, 74-75.

${ }^{11}$ B. Petranović, Srbija u Drugom svetskom ratu 1939-1945, Beograd 1992, 236.
} 
NOP-a i SSSR-a koji, te 1941. godine, nije blagonaklono gledao na forsiranje socijalne revolucije pored oslobodilačke borbe u Jugoslaviji. Naime, SSSR-u je bilo stalo do dobrih odnosa sa Velikom Britanijom, te je zbog situacije na sopstvenom frontu, po jugoslovenskom pitanju bio primoran da čini ustupke Velikoj Britaniji sve do pred kraj rata. Engleskoj, svakako, nije bilo $\mathrm{u}$ interesu odigravanje socijalne revolucije pod vođstvom KPJ u Jugoslaviji. ${ }^{12}$ I u parolama na kraju Titovih javnih istupanja osećalo se rangiranje saveznika: „Da žive Sovjetski Savez i njegovi saveznici“, ili „Živeli naši saveznici Sovjetski Savez, Engleska i Amerika“. ${ }^{13}$ Uistinu, partizanska propaganda se svodila na sledeću poruku: I mi treba da stvorimo državu i društveni sistem po ugledu na SSSR.

Gotovo svi dokumenti u arhivskoj građi Vojnog muzeja pokazuju neskrivenu želju partijskog i partizanskog rukovodstva ka divinizaciji Staljina i idolatriji prema Sovjetskom Savezu. Jedini dokument koji nekim svojim sadržajnim elementima ukazuje na tračak kolebljivosti i sumnje partijskog i partizanskog rukovodstva u sovjetsku armadu, jeste Izveštaj br. 3a, a reč je o govoru druga Staljina, predsednika „Komiteta za narodnu odbranu“. U Izveštaju se kaže: „Nad našom otadžbinom nadvila se opasnost. Kako se moglo dogoditi da je naša Crvena armija odstupila pred neprijateljem? Zar je nemačka fašistička vojska nepobediva, kako to tvrdi neprijateljska propaganda?" Potom slede reči koje svedoče o poljuljanom samopouzdanju, te dalje u dokumentu piše: „Moram istaknuti da je fašistička vojska ušla $u$ našu teritoriju pod povoljnijim uslovima, a naša vojska je imala nepovoljan položaj. Neprijatelj je koncentrisao protiv Sovjetskog saveza oko 170 divizija koje su stajale na našoj granici potpuno spremne, i očekivale signal za akciju, dok je našoj vojsci bilo potrebno da izvrši mobilizaciju. Veliki značaj ima i to što je fašistička Nemačka prekršila pakt o nenapadanju i iznenadno izvršila napad. Ona je dakle napadačka strana. Naša miroljubiva zemlja nije mogla da bude napadač. Kako je to moglo biti da je naša vlada sklopila pakt o nenapadanju sa fašističkom Nemačkom? Da li smo mi u tome napravili grešku?" Ipak, dokument se završava samouverenim tonovima kojima kao da se ponovo uspostavlja onaj od ranije trasiran put i kolosek ostajanja i istrajavanja u duhu „nepokolebljivosti“ i često isforsiranog osećanja samozadovoljstva. Citiramo: „Ovaj rat nije običan rat samo između dve vojske, ovo je rat Sovjetskog saveza protiv fašizma. Rat protiv ugnjetavanja i fašizma, rat u kojem nećemo samo likvidirati opasnost nad Sovjetskim savezom, već pomoći svim zarobljenim narodima." 14

${ }^{12}$ M. Pršić, Štampa NOP-a u Jugoslaviji 1941-1943, doktorska disertacija odbranjena na Univerzitetu u Beogradu 1993, 295.

${ }^{13}$ Isto, 296.

${ }^{14}$ VM, AG, i. b. 18422, Izveštaj br. 3a od 1941. godine, Govor druga Staljina, predsednika „Komiteta za narodnu odbranu“. 
Arhivalije Vojnog muzeja pokazuju elasticitet i dovitljivost partijskih i partizanskih vrhova u isticanju revolucionarnih parola. One su proturane $u$ svakom pogodnom trenutku, i gde god se to moglo, namerno organski vezane sa oslobodilačkom platformom. Dokaz ovoga jeste proglas Mladoj generaciji svih naroda Jugoslavije. U svakoj rečenici vidljiv je paritet između oslobodilačkih i revolucionarnih parola. U dokumentu čitamo: „Mlada generacijo radnog naroda! Ti koja si uvek htela samo mir i nacionalnu nezavisnost, ti koja si težila za sretnijom budućnošću stvaralačkog rada u slobodi i bratstvu svih naroda, ti imaš danas pravo da pitaš i moraš da znaš gde su i koji su pravi krivci za tvoje današnje patnje. " ${ }^{15}$ Sledi odgovor da su krivci nemački i italijanski imperijalisti, što već prejudicira klasnu obojenost onih koji šalju poruku. Već u prvoj rečenici se ističe težnja mladih ljudi da se uspostavi mir i nacionalna nezavisnost, dakle parole su neobojene klasnim porivima, ali u sledećem delu rečenice protura se ideal borbe za "sretniju budućnost“, odnosno uvijena forma revolucionarnih stremljenja i klasnog rata. ${ }^{16} \mathrm{U}$ dokumentu vidimo opreznost partijskih i partizanskih vrhova $u$ isticanju imperativa revolucionarne borbe i klasnih promena. Navodi se: „Mladi rodoljubi naše domovine! Savez komunističke omladine Jugoslavije koji se verno bori na strani svoga naroda, na strani naše drage i junačke Komunističke partije, za slobodu i srećnu budućnost svih naroda Jugoslavije, poziva vas u zajedničku borbu. Danas se ne radi o ovom, ili onom obliku političkog uređenja, danas se ne radi o pojedinačnim interesima ovih ili onih, danas se radi o oslobođenju Srba, Hrvata, Slovenaca, Crnogoraca, Makedonaca i drugih naroda naše zemlje od tuđinskog jarma, danas se radi o tome da proteramo okupatore iz naše zemlje i osvojimo svoju nezavisnost i slobodu! ‘17

Treći razlog glorifikacije Sovjetskog Saveza u napisima i forsiranje SSSR-a kao zemlje koju treba slediti, pretpostavljamo, proizilazi iz težnje partijskog i partizanskog rukovodstva da pred saveznicima i pred SSSR-om ublaži vidljivost svojih intencija da se napusti slepo kopiranje sovjetskih rešenja u složenim uslovima NOR-a. Partijsko i partizansko rukovodstvo je ugradilo sopstvenu inicijativu u kreiranju unutrašnjih prilika ${ }^{18}$ i imalo, reklo bi se, delimično originalan model funkcionisanja, saobražen specifičnoj situaciji na jugoslovenskom ratištu. Rukovodstvo je imalo svest o osobenosti partizanske borbe, pa je insistiranjem na čvrstim vezama sa Sovjetskim

\footnotetext{
${ }^{15}$ VM, AG, i. b. 18498, Proglas mladoj generaciji svih naroda Jugoslavije.

${ }^{16}$ Isto.

${ }^{17}$ VM, AG, i. b. 18417, Mlada generacija svih naroda Jugoslavije, Proglas CK SKOJ-a od jula 1941.

${ }^{18}$ M. Pršić, Štampa Narodnooslobodilačkog pokreta u Jugoslaviji 1941-1943. godine, doktorska disertacija odbranjena na Univerzitetu u Beogradu 1993, 295.
} 
Savezom i Kominternom, unekoliko, želelo da otkloni eventualna naslućivanja ruskog saveznika da partizani previše forsiraju bilo kakvu samosvojnu i emancipovanu borbu na jugoslovenskom ratištu.

Razume se, partizansko i partijsko rukovodstvo naglašavalo je istaknuto mesto Sovjetskog Saveza kao glavnog saveznika u antihitlerovskoj koaliciji. Velika Britanija je bila na drugom mestu po značaju. Arhivalije Vojnog muzeja otkrivaju intenciju partizanskih vojnih i partijskih vrhova da prikažu kako je u antihitlerovskoj koaliciji ipak Engleskoj bilo više stalo do dobrih odnosa sa Sovjetskim Savezom, iako je u praksi bilo obrnuto. Sovjetski Savez je, naime, bio spreman da zaobiđe interese Jugoslavije da se ne bi zamerao svom zapadnom savezniku. O napred rečenom svedoči Naš Izveštaj od 10. septembra 1941, a u kome se iznosi jedna navodna komunikacija između Lenjingrada i Londona, bez preciznih podataka o tome o kakvom je kontaktu reč i kada se i pod kojim okolnostima ovaj odigrao. Izgleda da je, po svoj prilici, on i izmišljen, u skladu sa tendencijom idolatrije prema Sovjetskom Savezu od strane partijskog i partizanskog rukovodstva. U dokumentu se kaže: „London zove Lenjingrad. Vojnici, mornari, avijatičari i radnici Lenjingrada, vojnici, avijatičari i radnici Londona čuli su danas vaš gromki glas koji je s Neve odjeknuo nad Temzom. Junački grade, grade revolucije, grade koji si izgrađen znojem miliona Rusa, svaki metak koji odjekne nad Nevom, odjeknuće u Londonu, London te pozdravlja. Živeo junački Lenjingrade." ${ }^{19}$ Partizanska propaganda je bila svojevrstan odgovor na intenzivnu i žestoku nacističku propagandu čija je oštrica bila usmerena i protiv SAD i Britanije. Izveštaj br. 16 od 19. jula 1941. sadrži pokušaj raskrinkavanja anti-angloameričke nacističke propagande. Partizanska propaganda ne štedi reči podrške angloameričkim saveznicima. Gebelsova propaganda se naziva lažima. ${ }^{20}$ Čini se potrebnim da iznesemo deo teksta iz dokumenta. U njemu se, naime, iznosi: „Na redovnoj preskonferenciji stranih dopisnika 1941. godine, drug Lozovski, zamenik šefa informacionog biroa, govorio je o reakciji nemačkih fašista na sporazum o zajedničkoj akciji u ratu protiv Hitlerove Nemačke, između Engleske i Sovjetskog saveza. Još pre potpisivanja tog istorijskog dokumenta nemačka propaganda tvrdila je, da Englesko-sovjetski pregovori o zajedničkoj akciji ne mogu dovesti do rezultata radi nemogućih zahteva Sovjetskog saveza. Kad je sporazum sklopljen, onda su počeli dokazivati, da sama činjenica što se vode pregovori, pokazuje beznadnost pozicija Engleske. Kad su se uverili, da takvim argumentima nije moguće sprečiti potpisivanje sporazuma, nemački radio i novine hitno su promenili ton i počeli Englesku plašiti boljševizmom. Budući da i to nije imalo uspeha, Gebels je ponovo reorganizovao propagandu. Izjavili su da

\footnotetext{
${ }^{19}$ VM, AG, i. b. 18443, Naš izveštaj, 10. septembar 1941.

${ }^{20} \mathrm{VM}, \mathrm{AG}, \mathrm{i}$. b. 18431, Izveštaj, br. 16, 19. jul 1941.
} 
englesko-sovjetski sporazum nema značaja. To su prihvatili svi nemački vazali i Italija. Ruska poslovica kaže: „Kud konj s kopitom, tuda kovač s čekićem". Međutim, ako sporazum nema nikakvog značenja, čemu treba da o tome govore? Fašisti su mobilisali ne samo berlinski radio i novine, nego su pokušali iskoristiti i američku štampu. Tako je Junajted Pres iz Berlina javila, da prema izjavama berlinskih krugova, sporazum ima značaj kao savez između Sovjetske i Engleske plutokratije. Ali, Hitler, Gebels i drugi fašistički magnati koji su se fašističkim preduzećem obogatili, vole da se posle masnog obeda zaslade antikapitalističkom demagogijom. Ove gluposti izazivaju samo homerski smeh. Nemački informacioni biro počeo je širiti misao da sporazum nije ništa bitno izmenio. Ovu genijalnu misao prihvatio je i radioBukurešt. Zatim su francuske novine donele da sporazum ima platonski karakter. I to se činilo berlinskoj propagandi malo. Oni su poslali u akciju i špansku artiljeriju. Berlinski radio izjavio je da se Engleska ovim sporazumom izbrisala iz evropske civilizacije. Šta će sada biti od jadne Engleske, pošto su je isključili iz civilizovanih zemalja? Nemačka diplomatska politička korespondencija kaže: „Engleska hoće sada uništiti Evropu. Eto kako bi Evropa bila u pogibelji da nema „dobrog“ Hitlera i njegovih pomoćnika. Ali Engleska nije sama, nju pomaže i Ruzvelt. Sada su dakle počeli pisati da sporazum ima protivevropski karakter. Dakle, najpre su pisali da sporazum nema nikakvog značaja, da je to platonski čin, a zatim da je to zavera protiv Kontinenta i vražja alijansa. Rusi vele u svojoj poslovici: „počeli sa zdravicom a završili sa opelom". Berlinska histerična vika svedoči da je sporazum udarac u srce Hitleru i njegovim banditima. Što se tiče optužbi protiv Čerčila i Ruzvelta, teško će se naći neko u Engleskoj i Americi ko će poverovati fašističkoj propagandi. Ako bi se takvih i našlo, to bi onda spadalo u patologiju, a ne u politiku." ${ }^{11}$

Partizanska propaganda je uspešno balansirala između podržavanja zapadnih saveznika i SSSR-a, procenjujući da je najcelishodnije imati političku podršku i jedne i druge savezničke strane. Vešto smišljena i dovitljiva partizanska propaganda morala je kroz napise $u$ štampi na sve načine ukloniti slabe tačke u lancu povezanosti sa SSSR-om, iznoseći da je ta država najverniji i najznačajniji saveznik u antifašističkoj borbi. Ovome, pak, treba dodati i postojanje fanatične odanosti partijskih i partizanskih rukovodstava Sovjetskom Savezu i Kominterni.

Važno je istaći da je stav SSSR-a bio potpuno obeshrabrujući za partizansko i partijsko rukovodstvo u smislu nepodržavanja njegove klasne borbe. Teško je bilo očekivati od SSSR-a da javno podržava socijalnu revoluciju, jer bi time izazvao podozrenje svog zapadnog saveznika. To SSSR nije

${ }^{21} \mathrm{VM}$, AG, i. b. 18431, Izveštaj, br. 16, 19. jul 1941. 
otvoreno priznao nego je negativan stav prema „levom skretanju“ i revoluciji objašnjavao mišljenjem da će „levo skretanje“ i pojava svojevrsnog vida sektaštva unazaditi NOP, smanjujući socijalnu osnovicu partizanskog pokreta i antifašističke borbe.

Druga grupa arhivalija jesu dokumenta koja popularišu borbu i politiku SSSR-a, ali takođe nude dosta informacija i sadržaja mimo uobičajenih egzaltiranih napisa o SSSR-u. Znatan broj dokumenata „raskrinkava, razobličuje i demaskrira“ petokolonaštvo i tzv. „domaće izrode kolaboracioniste“. Takvi dokumenti obiluju patetičnim frazama i floskulama koje pogoduju stvaranju tačno profilisane ličnosti koja će verno da se bori za interes partije, bez stvarnog uvida u značenje proklamovanih parola. O ovome govori jedan detalj iz glasila JNOF-a u Dalmaciji, br. 19 od 22. jula 1941. Tekst je pisan na srpskohrvatskom jeziku, latinicom, umnožen na geštetne$\mathrm{ru}$, na belom papiru, na dve strane, formata $34 \mathrm{x} 21 \mathrm{~cm}$. U jednoj, po našem mišljenju, ključnoj rečenici kaže se između ostalog da „u SSSR-u nema petokolonaštva i da ceo narod diše kao jedno biće, u cilju antifašističke borbe." Navodi se i „da radnici u SSSR-u dobro znaju zašto se bore, tj. za svoje fabrike, zemlju, za svoje domove, porodice, odn. za svoju domovinu." Karakteristična je rečenica da domovina za njih nije prazna fraza, nego „parola puna sadržaja.“22 Ovom rečenicom kao da se želelo naglasiti da su ciljevi koje proklamuje partijsko i partizansko rukovodstvo sasvim konkretni i lišeni bilo kakve imaginarnosti i apstrakcije. Proklamovane revolucionarne dogme uistinu su mogle biti izvesna apstrakcija za običnog srpskog seljaka.

Partizanska propaganda je trebalo da na svaki način kroz napise $u$ štampi konkretizuje parole kojima je KPJ uticala na svest prosečnog srpskog seljaka, obasutog nerazumljivim dogmama koje su pretendovale da budu pokretačka snaga na ustanak protiv okupatora. U listu Borba od oktobra 1941, pompeznim rečenicama se ističe kako Hitler gubi rat na Istočnom frontu. Da bi se naglasila podrška SSSR-u, partijsko i partizansko rukovodstvo u svojoj štampi kritikuje Gebelsov propagandni ured, nazivajući nemačku propagandu lažima jer iznosi „fantastične" brojke o sovjetskim gubicima, a u cilju prikrivanja pred nemačkim narodom i svim drugim narodima sveta, surove istine da Hitler na Istočnom frontu gubi rat, kako se kaže u dokumentima, „svakim danom sve jasnije i odlučnije“. ${ }^{23} \mathrm{U}$ istom listu KPJ, Borbi, ogromna pažnja se posvećuje organizaciji organa revolucionarne vlasti - narodnooslobodilačkim odborima. Dužnost odbora kao privremenih nosioca celokupne vlasti jeste da organizuju aktivnost celog naroda, da bi se partizanima na frontu obezbedilo sve što je potrebno. U toj aktivnosti trebalo je da odbori sarađuju sa štabovima partizanskih odreda. Druga

\footnotetext{
${ }^{22}$ VM, AG, i. b. 18435, Izveštaj, br. 19, glasilo JNOF Dalmacije, 22. jul 1941.

${ }^{23}$ VM, AG, i. b. 18392, Borba, oktobar 1941.
} 
funkcija NOO-a bila je obezbeđivanje reda u pozadini i bespoštedna borba protiv „pete kolone“. Treća uloga NOO-a ogledala se u organizaciji snabdevanja i ishrane stanovništva i što pravilnijem razvoju privrednog života, trgovine i saobraćaja u interesu fronta i naroda. Poslednja, četvrta funkcija odbora bila je da svim sredstvima učvršćuju vezu fronta i pozadine. ${ }^{24}$

Ovi napisi Borbe bili su svojevrsna apologeza novih revolucionarnih vlasti, tim pre što se već na početku, pre iznošenja glavnih funkcija NOO-a, ne štede reči u objašnjavanju zašto se stvaraju odbori i zbog čega se ne ostaje pri starim opštinskim upravama i žandarmerijskim stanicama. Kao razlog se navodi da su ove, kako dokumenta precizno kažu, „leglo petokolonaštva koje pomaže okupatoru i šteti borbi““. ${ }^{25}$

Ipak, stvaraoci ovih napisa morali su u ovom tekstu da podvuku kako je i među članovima opštinske uprave bilo poštenih ljudi i da je njima, kao časnim rodoljubima, otvoren put da budu birani u NOO-e, naravno ukoliko dobiju poverenje naroda. ${ }^{26}$

Interesantno je da dokumentarna građa Vojnog muzeja ističe kako su NOO nastojali da okupe što više građana nezavisno od njihovog političkog ubeđenja, ukoliko su ovi bili patriotski raspoloženi i prihvatali borbu za narodno oslobođenje. To je, verujemo, činjeno iz dva razloga. Prvi se sastoji $\mathrm{u}$ intenciji partijskog i partizanskog rukovodstva da pred srpskim narodom, vernim legitimnim oblicima vlasti Kraljevine Jugoslavije, unekoliko prikriju u osnovi antilegitimistički istup protiv centra vlasti na čelu sa kraljem i Jugoslovenskom vladom u izbeglištvu. Drugi razlog deklarativnog „širenja ru$\mathrm{ku}$ „građanskim snagama ogleda se $\mathrm{u}$ nameri NOP-a da suzbije negativna raspoloženja SSSR-a povodom stvaranja revolucionarnih organa vlasti, čime se htelo prikriti nastojanje da se oslobodilačka borba proširi u revolucionarnu, a koju Sovjetski Savez nije odobravao, ne želevši da se zamera Velikoj Britaniji do čijeg mu je partnerstva $u$ antihitlerovskoj koaliciji bilo neobično stalo." ${ }^{27}$

Treću, malobrojniju grupu arhivalija čine dokumenta raznovrsnih sadržajnih karakteristika koje se odnose na popularizaciju politike KPJ, izražavanje neprijateljstva prema Ravnogorskom pokretu i slično. Sadržaji koji veličaju SSSR vidljivi su samo u tragovima. Ipak, neumitno je i njihovo prisustvo. Nekoliko važnih dokumenata bavi se popularizacijom i svojevrsnom apologezom politike KPJ. U tom smislu je zanimljiv tekst pisan latinicom, na srpskohrvatskom jeziku, umnožen na šapirografu, na 26 numerisanih

${ }^{24}$ Isto.
${ }^{25}$ Isto.
${ }^{26}$ Isto.
${ }^{27}$ B. Petranović, Revolucija i kontrarevolucija u Jugoslaviji 1941-1945, knj. 1, Beograd 1983, 216-218. 
strana, formata 20,5 x $17 \mathrm{~cm}$. Naslov lista Srp i čekić napisan je rukom, mastilom. U tekstu se ističe jedna od pomenutih sadržajnih karakteristika partizanske štampe - propagiranje potrebe stvaranja širokog fronta radnika i seljaka i svih antifašistički raspoloženih ljudi bez obzira na veru i nacionalnost. Da bi njihova borba bila što uspešnija, neophodno je učvrstiti i ojačati partijsku organizaciju, sprovesti strogu podelu rada, najstrože poštovati pravila konspiracije, očistiti redove od nepouzdanih elemenata, pojačati budnost i oprez prilikom primanja novih članova i pojačati kontrolu rada svakog pojedinca, te omasoviti partijski rad. ${ }^{28}$ Interesantne su pokretačke parole partizanske propagande, odnosno agitaciona delatnost partijskih rukovodstava u smislu obilate eksploatacije krilatica u ideološkim tekstovima. Takav je slučaj sa jednim Proglasom mladoj generaciji svih naroda Jugoslavije koji je potekao od Centralnog komiteta SKOJ-a, a koji se završava oduševljenjem sa nekoliko dobro poznatih parola koje su imale za cilj stimulisanje i mobilizaciju masa. Pri dnu dokumenta su parole: Živilo jedinstvo mladih naraštaja Hrvatske, Srbije, Crne Gore, Slovenije, Makedonije, Vojvodine i Bosne, protiv imperijalista, za punu slobodu i nezavisnost svih naroda Jugoslavije! Sledeća parola glasi: Živilo jedinstvo radničke, seljačke i školske omladine! potom: Dole imperijalistički rat! I neizbežna parola: Živio Sovjetski Savez, tvrđava mira, slobode i nezavisnosti naroda! ${ }^{29}$

Interesantno je da se mlada generacija u ovom Proglasu ne poziva na raskidanje sa sopstvenim nacionalnim tradicijama, naprotiv, ona se poziva da čuva „slobodarski duh svojih dedova“, svoj jezik i nacionalnu kulturu. ${ }^{30}$ To se može objasniti velikom nacionalnom svešću srpskog naroda i omladine koja je bila stožer širih okupljanja, i zazorom novih revolucionarnih vođa od potpunog razbijanja srpskog nacionalnog samosvojnog bića koje je, itekako, u ranoj fazi rata moglo okupiti napredne i borbene antifašističke elemente. U tom smislu je važan Proglas CK SKOJ-a iz jula 1941. u kojem se mlada generacija Jugoslavije poziva da zbije front i protera okupatora iz zemlje i stvori nezavisnost i slobodu svom narodu. Poseban pasus ovog teksta odnosi se na obraćanje partijskih rukovodstava srpskoj omladini da stane na put fašističkom teroru koji „želi da iskoreni njeno srpsko ime“. Srpski narod nikad nije hteo biti tuđi rob. ${ }^{31}$

Srpska omladina se ovim napisom poziva da „se pokaže dostojnom slavne tradicije pobunjene raje i srpskih hajduka i da nastavi delo srpskih narodnih ustanika iz prošlosti do konačnog oslobođenja Srba“. ${ }^{32}$

\footnotetext{
${ }^{28}$ VM, AG, i. b. 18405, Srp i čekić, list CK KP Hrvatske.

${ }^{29}$ VM, AG, i. b. 18499, Proglas mladoj generaciji svih naroda Jugoslavije.

${ }^{30}$ Isto.

${ }^{31}$ VM, AG, i. b. 18417, Proglas CK SKOJ, jul 1941.

${ }^{32}$ Isto.
} 
Ovde je vidljiv preterano naglašen blagonaklon stav prema srpskom narodu na kojeg su antifašističke snage partijskog i partizanskog rukovodstva sigurno mogle najozbiljnije da računaju. Takođe, prva godina rata je još uvek odisala duboko uvreženim ostacima vezanosti sa institucijama prošlosti i tradicijom u srpskom narodu, i tu činjenicu partijska i partizanska rukovodstva nisu smela i mogla tako lako da prenebregnu. Pomenimo list Vesti, štaba užičkog narodno-oslobodilačkog partizanskog odreda od 3. oktobra 1941. Tu se ističe da „pobedonosni srpski narodnooslobodilački partizanski odredi, progoneći gnusne okupatore sa svoga nacionalnog tla, produžuju onu slavnu tradicionalnu borbu u kojoj je nad svetlim srpskim mačevima lepršala srpska zastava, crvena, plava, bela. Zato su prihvatili kao znamenje svoje borbe za narodno oslobođenje taj trobojni srpski znak."33 Pretpostavku da je partijsko i partizansko rukovodstvo gajilo respekt prema borbi srpskog naroda, potkrepljuje i Borba br. 1 od 1941. godine. U dokumentu se navodi: „Srpski partizani se ne boje Hitlerovih divizija i pravo je vreme za nacionalni rat srpskog naroda koji se ne može svršiti drugačije, nego punom pobedom srpskog naroda“. Dalje se ističe: „Hitler nikada više neće biti gospodar Srbije, jer je dan njegovog sloma blizak". Isti dokumenat beleži: „Hitler nije u stanju da uguši sveti nacionalni ustanak srpskog naroda. ${ }^{34}$ U Biltenu br. 7 i 8 od 1. oktobra 1941. ističe se: „Srpski partizani nisu više malene čete koje napadaju iz šuma na neprijatelja. To su danas krupne borbene jedinice čvrsto povezane štabovima, sposobne za krupne operacije protiv neprijatelja srpskog naroda. “35 Dalje, interesantan je Naš izveštaj br. 75 od 21. septembar 1941, u kojem stoji: „Evo zato su okupatori tako besni, jer vide da srpski narod nisu porobili, jer Srbija nije krava muzara za njih, već opasno bojište gde oni stalno dobijaju osetljive udarce. ${ }^{36}$ Pozitivan stav partijskog i partizanskog rukovodstva prema borbi srpskih partizana ogleda se u Našem izveštaju br. 64 od 10. septembra 1941: „Borba se sve više razmahuje i razvija u pravcu opštenarodnog ustanka. Evo šta rade srpski narodni partizani. Oni zaustavljaju putničke vozove, održavaju s putnicima zborove, objašnjavaju značaj narodne borbe i ulogu partizana. To izaziva ogromno oduševljenje kod naroda. “37 Ipak, prisutna je izvesna opreznost $u$ ekspresiji blagonaklonosti, što potvrđuje dokument u kojem se naglašava: „Središte borbe evropskih naroda protiv fašizma jeste Srbija, koja se sa ostalim narodima Jugoslavije junački bori i neprijatelju zadaje teške udarce." Dakle, ideja zajedničke borbe svih naroda Jugoslavije potencira se $u$

\footnotetext{
${ }^{33}$ VM, AG, i. b. 18391, Vesti, 3. oktobar 1941.

${ }^{34} \mathrm{VM}, \mathrm{AG}, \mathrm{i}$. b. 18392, Borba, br. 1 od 1941.

${ }^{35} \mathrm{VM}, \mathrm{AG}, \mathrm{i}$. b. 18496, Bilten, br. 7 i 8, 1. oktobar 1941.

${ }^{36}$ VM, AG, i. b. 18396, Naš izveštaj, br. 75, 21. septembar 1941.

${ }^{37}$ VM, AG, i. b. 18443, Naš izveštaj, br. 64, 10. septembar 1941.
} 
odnosu na naglašavanje borbe srpskog naroda koji je, realno, bio glavni antifašistički subjekt. ${ }^{38}$ Uvažavanje oslobodilačke borbe srpskog naroda vidljivo je u Vestima od 3. oktobra 1941, gde stoji: „U borbi se omladina Srbije napajala viteštvom golorukih seljaka koji su samo sa ugarkom u ruci skočili svi kao jedan čovek da izvojuju svoju slobodu, i dokazala da srpski narod još ima svoje Obiliće. “39 Interesantan je tekst iz istog dokumenta koji sadrži dosta patosa i pokušaja da se na metaforičan način utiče na formiranje borbenih osećanja: „Drhti srce Srbina, kopaju konjici zemlju, nestrpljivi da krenu u sveti boj, maša se ruka puške, a puška ćuti - ne puca. U tim teškim, kišnim danima, ispucana usta srpskog vojnika, suva i gladna, bacala su teško prokletstvo na izrode koji nas prodadoše za lažan sjaj fašističkih bandita. Narod je ostavljao svoj dom spreman da pođe u novu Albaniju, na nove muke, s nadom da će se jednom kao pobednik spustiti u svoja sela i uživati plodove svoje slobode. Ali narodna borba bi brzo ugušena. Izdani, napadnuti sa svih strana od strvinara, srpski radnik i seljak za momenat odložiše oružje. Započe krvava epopeja stradanja, leleka srpskih majki i sestara. Zavijen u crno, stoji sav srpski narod i ćuti-ako je škrgut zuba ćutanje. Na zvon borbe za slobodu ustaju borci, planinama i šumama gori plamen, nevidljivi plamen u grudima boraca i preti da sažeže sve krvnike i silnike". ${ }^{40}$

Blagonaklon stav KPJ prema srpskom narodu na samom početku rata imao je, pretpostavljamo, i pragmatičan cilj otklanjanja bilo kakvih sumnji u postojanje animoziteta Partije prema srpskom narodu kao glavnom i nezaobilaznom antiokupatorskom činiocu na koji se najviše računalo, budući da je Partija u ranoj fazi svoje istorije neretko izjednačavala srpski narod sa buržoazijom. On je, navodno, „držao pod svojom čizmom ostale, tzv. ugnjetavane narode, a među njima pre svih hrvatski narod." Pri tom nije uzimana u obzir činjenica da je i sam taj srpski narod bio eksploatisan kao i ostali narodi od svoje i ostalih buržoazija naroda Jugoslavije. U samoj KPJ, srpski komunisti su gotovo među poslednjima stvorili svoju nacionalnu partijsku organizaciju, posle Slovenaca, Hrvata i Makedonaca, tek maja $1945 .^{41}$

Prva ratna godina je bila obeležena i nastojanjem partizanske propagande da raskrinka i kako sama kaže „razobliči“ i „demaskira“ pripadnike Ravnogorskog pokreta. U tom smislu je važan tekst na srpskohrvatskom jeziku, ćirilici, umnožen na hemijskoj presi na 3 numerisane strane, formata 34 x $21 \mathrm{~cm}$. U pitanju je letak štaba beogradskog bataljona NOV Jugoslavije

${ }^{38}$ VM, AG, i. b. 18482, Naš izveštaj od 1941.

${ }^{39}$ VM, AG, i. b. 18391, Vesti štaba užičkog narodno-oslobodilačkog partizanskog odreda, 3. oktobar 1941 .

${ }^{40}$ Isto.

151.

${ }^{41}$ B. Petranović, Srbija u Drugom svetskom ratu 1939-1945, Beograd 1992, 150- 
iz 1941. godine, kako je neprecizno formulisano u samom dokumentu, a pominje se „izdajnička“ delatnost Milana Nedića i Draže Mihailovića. ${ }^{42}$ Naravno, reč je o pogledu zasnovanom na uvreženom mišljenju o Dražinom kolaboracionizmu, ali interesantno je odsustvo „teških“ i uvredljivih reči prema pripadnicima Ravnogorskog pokreta. Čak se i pominje da su oni sklopili sporazum sa partizanima u cilju vođenja zajedničke borbe. Ovaj prilično uravnotežen, obestrašćen rečnik partijskih i partizanskih rukovodstava može se objasniti njihovom svešću da se od Ravnogorskog pokreta mogla očekivati korist tokom 1941. godine i da su postojale planirane akcije združenih partizanskih i snaga pripadnika Ravnogorskog pokreta.

Ovu pretpostavku potkrepljuje Bilten Vrhovnog štaba od 20. oktobra 1941. u kojem se ističe kako u „razbijanju Ljotićevaca hrabro učestvuju nesalomivi partizani i pravi srpski četnici." Borba je počela dobijati sve šire razmere i u nju stupaju novi partizanski bataljoni i pošteni četnički odredi, navodi Bilten. ${ }^{43}$ Potvrdu toga da je partizanska štampa bila, u neku ruku, blagonaklona prema Ravnogorskom pokretu u oktobru i novembru 1941, nalazimo u Biltenu Vrhovnog štaba u kojem se jasno kaže kako mnoge gradove u Srbiji kontrolišu i čvrsto imaju na oku ne samo herojski partizani, nego i deo savezničkih vojnih četnika. ${ }^{44}$ Godina 1941 , svakako nije bila pogodno vreme za eksplicitnu ekspresiju nezadovoljstva četnicima, te nailazimo na prilično sofisticirane i blage izraze koji se povezuju sa pripadnicima Ravnogorskog pokreta. To je bilo svakako u vezi sa mudrim taktiziranjem partizanskog vrha koji nije želeo otvoreno da se zamera sa njima jer su oni bili veoma popularni u narodu. Pomenuti Proglas iz 1941. godine, prilikom obraćanja srpskoj omladini govori joj da se hrabro bori za svoju slobodu i da prezre „sve one koji savetuju čekanje i štednju vremena, jer još nije došao čas". ${ }^{45} \mathrm{Tu}$ se, izvesno, misli na pripadnike Ravnogorskog pokreta, ali partizanska propaganda još uvek ne želi to otvoreno da kaže i direktno se razračuna sa potencijalnim saveznikom u zajedničkoj oslobodilačkoj borbi. Ova tendencija nezameranja koja provejava partizanskom štampom prisutna je i u Izveštaju br. 14 od 18. jula 1941. Tu se ističe da se u Srbiji pod imenom četnika „razumeju narodni borci koji su se još pod Austrougarskom borili protiv tuđinskih vlasti. Tamo nastaju nacionalni četnički odredi koji se bore protiv tuđinskog osvajača. Ali ti se odredi sve više slivaju zajedno sa partizanskim odredima, te pod vođstvom Kompartije stvaraju jedinstveni nacionalno-oslobodilački front za borbu protiv fašističkog osvajača." ${ }^{46}$

\footnotetext{
${ }^{42}$ VM, AG, i. b. 1840, Letak štaba beogradskog bataljona NOV Jugoslavije iz 1941. godine.

${ }^{43}$ VM, AG, i. b. 18490, Bilten Vrhovnog štaba, 20. oktobar 1941.

${ }^{44}$ VM, AG, i. b. 18946, Bilten Vrhovnog štaba.

${ }^{45}$ VM, AG, i. b. 18417, Proglas CK SKOJ, jul 1941.

${ }^{46} \mathrm{VM}$, AG, i. b. 18393, Izveštaj, br. 14, 18. jul 1941.
} 
Članak iz Biltena donosi tekst u kojem se jasno vidi da se partizanska propaganda sa ustručavanjem okomljuje na Ravnogorski pokret. Ona ne govori nimalo pohvalno o njemu, ali se snebiva da jasno naglasi da je četnički pokret protivnik partizanskog. Iznesimo deo sadržaja ovog dokumenta: „Dižu se narodi Jugoslavije na boj sa fašističkim zverima-okupatorima, jer sada je kucnuo čas. Sada je kucnuo čas kada herojska Crvena armija i sav sovjetski narod zadaje udarac za udarcem fašističkim pljačkaškim hordama. Mi Južni Sloveni moramo u toj svetoj oslobodilačkoj borbi Slovena doprineti svoj deo. A ko će nama doneti slobodu ako se mi sami nećemo boriti? Zar nije podlost i sramota govoriti narodu da nije vreme za borbu. Zar ne znači to isto što i kazati, neka ginu za nas braća Rusi a mi ćemo onda na gotovo. Takvo gledište je podlo i sramotno, nedostojno našeg naroda. Istorija ovo ne bi oprostila našem narodu. To bi bila izdaja najgore vrste. ${ }^{47}$ Unekoliko pomirljiv odnos prema Ravnogorskom pokretu nazire se $u$ dokumentu $u$ kojem se navodi: „Ima sektaških pojava prema saveznicima u borbi, ili prema sada još neutralnim grupama četnika, koje još nisu voljne da stupe u borbu, ali nam nisu neprijateljske. Sa svim tim grupama mora se izbegavati svaki sukob. Treba takvima strpljivo objašnjavati da je baš sada čas za odlučnu borbu protiv neprijatelja srpskog naroda." 48

U arhivalijama Vojnog muzeja ilustrativno se prikazuje težnja partizanskog rukovodstva da pozove $u$ borbu sve narode bez obzira na nacionalno opredeljenje. ${ }^{49}$ I ovo se ne može objasniti samo širokim vizionarskim pogledima KPJ lišenim uskogrudosti, nego i svojevrsnom reakcijom na četničku propagandu koja je forsirala blagonaklon stav prema svim poštenim Hrvatima, Slovencima i Muslimanima. ${ }^{50}$ Ipak, neminovno je napomenuti da je politika propagiranja jedinstvenosti jugoslovenskog nacionalnog bića oličena kroz parolu bratstva i jedinstva, u stvari direktna posledica politike Kominterne, koja je insistirala na ideji formiranja jake jugoslovenske države i jugoslovenskih naroda ne iz sentimentalnih i romantičarskih ideja njihove međusobne povezanosti, nego zbog toga što je jedinstven narod u jedinstve-

${ }^{47}$ VM, AG, i. b. 18489, Članak iz Biltena Glavnog štaba narodno-oslobodilačkih partizanskih odreda Jugoslavije.

${ }^{48}$ VM, AG, i. b. 18496, Bilten Vrhovnog štaba narodno-oslobodilačkih partizanskih odreda Jugoslavije br. 7 i 8, 1. oktobar 1941.

${ }^{49}$ VM, AG, i. b. 18498, Proglas mladoj generaciji svih naroda Jugoslavije; VM, AG, i. b. 18505, Proglas CK KPJ; VM, AG, i. b. 18417, Proglas CK SKOJ, Mlada generacija svih naroda Jugoslavije; VM, AG, i. b. 18484, Naš izveštaj, br. 119, 16. decembar 1941; VM, AG, i. b. 18404, Bilten Glavnog štaba narodnooslobodilačkih partizanskih odreda Jugoslavije; VM, AG, i. b. 18499, Proglas mladoj generaciji svih naroda Jugoslavije; VM, AG, i. b. 18486, Naš izveštaj, br. 9; VM, AG, i. b. 18482, Naš izveštaj, br. 117, 9. decembar 1941; VM, AG, i. b. 18405, Srp i čekić, organ CK KP Hrvatske; VM, AG, i. b. 18946, Bilten Vrhovnog štaba narodnooslobodilačkih partizanskih odreda Jugoslavije.

${ }^{50}$ M. B. Matić, Ravnogorska ideja u štampi i propagandi, Beograd 1995, 43. 
noj državi jedino bio sposoban da se odupre eventualnoj agresiji imperijalističkih sila. ${ }^{51}$ Partizanska propaganda, čak, nije bila lišena protivrečnosti i isključivosti i da je dolazila u kontradikciju sama sa sobom. Ono što je paradoksalno, dokumenti arhivske građe Vojnog muzeja koji zdušno propagiraju jedinstvo svih naroda Jugoslavije, ukazuju na isključivosti partijskih vrhova po ovom pitanju.

U dokumentu pod nazivom Mladoj generaciji svih naroda Jugoslavije piše: „Mlada generacijo svih naroda Jugoslavije, ti to možeš. Ako budeš znala da zbiješ svoje redove u moćan jedinstveni front na strani svoga naroda, na strani radničke klase i njene avangarde KPJ koja se i danas, kao uvek, hrabro bori na čelu naroda protiv imperijalističkih zavojevača, za nacionalno oslobođenje i svetlu budućnost svih naroda Jugoslavije. " ${ }^{2} \mathrm{U}$ ovom iskazu zapažamo dve stvari. Prvo, u dokumentu se eksplicitno navodi kako mlada generacija treba da se bori na strani svog naroda, a ne kaže se, kako bi bilo očekivano, da mlada generacija treba da bude eksponent svih naroda Jugoslavije i da treba da stoji ispred svih naroda Jugoslavije. Drugo, u dokumentu se navodi da mlada generacija treba da se bori na strani radničke klase i njene avangarde, KPJ, a ne spominje se seljaštvo niti bilo koji drugi sloj društva. Ipak, partijsko i partizansko rukovodstvo neretko je bilo svesno da se moralo oslanjati na široke mase ne bi li uspešno vodilo borbe sa neprijateljem. Tako se partizanski pokret identifikovao, barem verbalno, sa sveopštim narodnim pokretom. Prilikom iznošenja da će se partizani boriti protiv okupatora, navodi se da će se uništavati bez milosti sve što padne $u$ ruke narodnih boraca. U Biltenu Vrhovnog štaba od 20. oktobra 1941. kaže se: „Borba je počela zauzimati sve šire razmere. U borbu stupaju sve novi i novi partizanski bataljoni i pošteni četnički odredi. U toj borbi na život i smrt, neće biti nikakve milosti ni za okupatore ni za domaće izrode. Uništavaćemo bez milosrđa sve što padne u ruke narodnih boraca. Uništavaćemo sve ono što je diglo okrvavljenu ruku na našu decu, na naše majke i očeve, na naše žene. Uništavaćemo one koji pale i ruše naša mirna sela i varoši. Neprijatelj će skupo platiti za svoje krvave zločine.

Nevina krv dece, žena i staraca vapi za osvetom i mi ćemo je osvetiti-stostruko osvetiti. Krv za krv, jedan život za stotinu pasjih okupatorskih i izdajničkih života. Borićemo se do poslednjeg daha, borićemo se do potpunog uništenja okupatorske fašističke nemani. Borićemo se dok i poslednji fašistički bandit ne napusti našu zemlju. Na kostima fašističkih bandita izgradićemo naša sela, naše varoši. “"

${ }^{51}$ B. Petranović, Revolucija i kontrarevolucija u Jugoslaviji 1941-1945, knj. 2, Beo$\operatorname{grad} 1983,252$.

${ }^{52}$ VM, AG, i. b. 1849, Mladoj generaciji svih naroda Jugoslavije.

${ }^{53}$ VM, AG, i. b. 18490, Bilten Vrhovnog štaba, 20. oktobar 1941. 
Marijana Jovelić

\author{
THE PARTISAN PROPAGANDA IN SERBIA IN 1941 \\ IN THE ARCHIVES OF THE SERBIAN MILITARY MUSEUM
}

\title{
Summary
}

The Partisan propaganda had three layers. The first layer represents a glorification and blinded idolatry towards the USSR. The second layer was depicted by favoring the social revolution, and it is only the third layer which shows that actually only one goal of the National Liberation War and the Party and Partisan governance was the liberation struggle. The archives of the Military Museum tell in favour of the above mentioned, so that there are mostly documents which corroborate the tendency of the Partisan and Party governance to an uncritical worshipping of the USSR. According to number, at the second place are archival documents which tell in favour of subversive aims of the National Liberation War in the context of insisting on a social revolution, and only at the third place there are archives in which the liberating character of the National Liberation War is glorified. A considerable part of the archival material tells of how, during the first war year, the leadership of the National Liberation War expressed a certain kind of respect towards the opponent displayed in the Ravna Gora Movement, and by this showing understanding for the fact that the Ravna Gora Movement was really very popular with the Serbian people whose support it was aimed at. The year 1941 was significant because of two reasons. Firstly, during that period the military units of the National Liberation War were being formed in a complete strategic isolation, without any backing of the allies and with a rather reserved support of the Comintern. Secondly, the military press as a means of political propaganda was diverse at that time, sprung out of the variety of concrete "local" conditions and a different level of power and organization of the Partisan units, and as such it is interesting for observation. 